\title{
AVERAGE EFFECTIVE TAX RATES OF TURKEY IN EU ACCESSION PROCESS
}

\author{
Doç. Dr. Başak Tanınmış YÜCEMEMIŞ̧* \\ Kazım Okan EROL ${ }^{\dagger}$
}

\begin{abstract}
Özet
Bu çalışma, mali federalizm çerçevesinde ekonomik entegrasyon ve vergi gelirleri arasındaki ilişkiyi dikkate alarak, Türkiye'nin vergi gelirlerinin AB üyelik süreci içerisinde nasıl değiştiğini açıklamaktadır. Makalenin ana konusu 1990 yılından itibaren Türkiye'nin ekonomik bütünleşme sürecinin vergi gelirleri üzerindeki etkisini ortaya koymaktır. İleri derecede ekonomik bütünleşme ülkeler arasındaki üretim faktörlerinin hareketliliğini arttırmakta ve bu ülkelerin vergi gelirlerini etkilemektedir. Teorik olarak açılanan bu hususlar, Türkiye-AB ekonomik bütünleşme süreci ve vergi gelirleri arasındaki ilişki basit korelasyon analizi ile test edilecektir.
\end{abstract}

Anahtar kelimeler: Ekonomik bütünleşme, ortalama efektif vergi oranı, AB-Türkiye ilişkileri, ekonomik küreselleşme, vergi politikası

Jel Codes: F15, H20, H30, H71

\begin{abstract}
This study aims to explain how public revenue system of Turkey has evolved in an economic integration process that explores the correlation between economic integration and tax revenues from a fiscal federalism perspective in the EU and Turkey. Main research problem of this study is that to analyze how economic integration affected tax revenues of Turkey since 1990. High degree of economic integration increases factor mobility and affects public revenues of member states. Those theoretical inferences will be tested by EU-Turkey economic integration case with simple correlation analysis.

Keywords: Economic integration, average effective tax rate, EU-Turkey relations, economic globalization, tax policy
\end{abstract}

Jel Codes: F15, H20, H30, H71

\footnotetext{
* Assoc.Prof.(Ph.)Marmara University, Institute of Banking and Insurance, basakyuce@marmara.edu.tr

$\dagger$ Marmara University, European Union Institute
} 


\section{Introduction}

European economic integration has changed economic governance of the EU and also fiscal policies of member states deeply. Supranational structure of European Central Bank (ECB) has forced national states to comply their economic policies with this new economic framework. Triggered by a global financial crisis, Euro-zone crisis has shown us that monetary policy conducted by ECB is not a convenient policy unless it is supported by fiscal coordination of member states' policies. Tax policy is an indispensable and important component of fiscal policy and usually most of the countries are reluctant to reform tax systems in short term. However in an economic integration process tax revenues of member states and candidate countries are not independent from supranational economic governance and each state's own tax policy.

High degree of economic integration gives rise to factor mobility and affects public finance models and also tax system of a specific country. As a unitary state Turkey, has a long relationship with the EU which started formally in 1961 with an Ankara Agreement. In 1996, a Customs Union was established between Turkey and the EU. We will focus on economic convergence among Turkey and EU member states after 1990. Our average effective tax rate (AETR) estimations will be tested whether there is a direct relationship between AETRs and economic integration indicators.

Turkey's financial liberalization has accelerated since 1980 government decisions on exchange rate regime and especially on capital movements. In 1980, exchange rate regime changed rapidly, import substitution model replaced by export-oriented growth model and free movement of capital established by the government. Value added tax became law in 1984 which is the main tax revenue source of the government and a significant tax burden on consumption. Decreasing import tax revenues, due to 24th of January 1980 decisions, have caused a new type of taxation for Turkey in order to compensate revenue loss of Turkish government.

In 2002 Excise Tax Law has been accepted by Turkish Parliament as a part of EU accession reforms. Having first applied Excise Tax Law, has changed Turkish Tax system deeply. The share of consumption has increased relative to capital and labor taxation. Turkey, as a candidate for a full EU membership since 2004, has already been affected by EU's economic conditions and European tax policies. These interdependencies are more effective after 1995 Customs Union Decision. Turkey has followed European economic integration path as a financial and trade liberalization policy tool. This economic anchor also means 
opening Turkish markets to international trade. Moreover this policy accelerated liberalization of capital/ good markets of Turkey in a global environment.

The rest of paper unfolds as follows: section one analyzes economic indicators of convergence between Turkey and EU by using trade and foreign direct investment statistics. Then, Turkish national revenue statistics and its comparability with international statistics will be discussed in section two. Literature review about economic integration and tax revenues will be shown in section three. In section four, we calculate average effective tax rates on labor and capital for Turkey. Section five discusses the calculation method of average effective tax rates and results. Final section concludes with policy recommendations.

\section{Economic Integration of Turkey to European Single Market}

After Turkish government's trade and capital movement liberalization policy, the volume and variety of trade between Turkey and EU have increased. Customs Union Decision also changed trade patterns directly.

Graphic-1 shows us Turkish import and export volume from and to the EU, is changed dramatically after 1995 decision which removes trade barriers on industrial goods between Turkey and the EU. First, the gap between import and export has increased after 1995 but it has stabilized in 2001. Export performance of Turkey has accelerated after Customs Union decision not only to the EU but also to EU's trade partners. We may also conclude from the graph that in crisis times merchandise trade gap increases because of exchange rate fluctuations. The effect of 2001 Turkish financial crisis and 2008 global financial crisis are seen on graphic 1 .

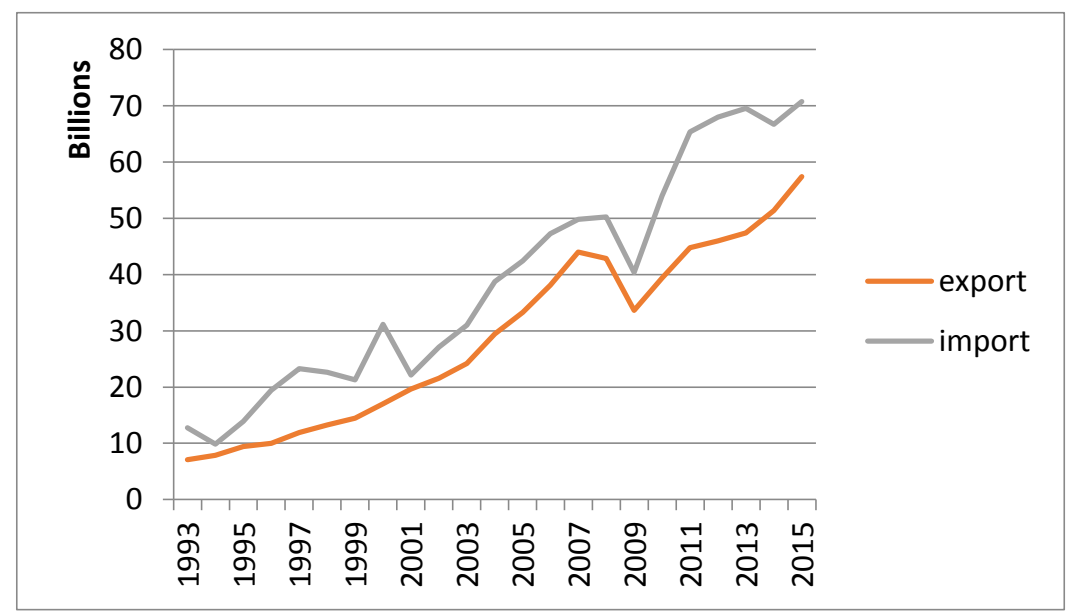

Graphic 1: Turkey's Exports to EU-27 and Imports from EU-27 (in billion Euro, 1993-2015)

Source: Turkish National Statistics Agency trade statistics. 
Another important indicator of economic integration is foreign direct investment (FDI) flows between two economic regions. Determinants of FDI flows are more complicated than trade flows since FDI's are not only affected by economic conditions but also legal system, political conditions and socioeconomic structure of any country. Moreover, FDI flows may occur in different forms as a market entry option and these forms are affected by different economic and political conditions. For instance merger and acquisitions are more dependent on economic fluctuations contrary to green-field investments.

FDI flows between Turkey and EU-27 have also been evolved in Turkish accession process to the EU. Graphic 2 represents the FDI flows between EU-27 and Turkey from 1993 to 2015 .

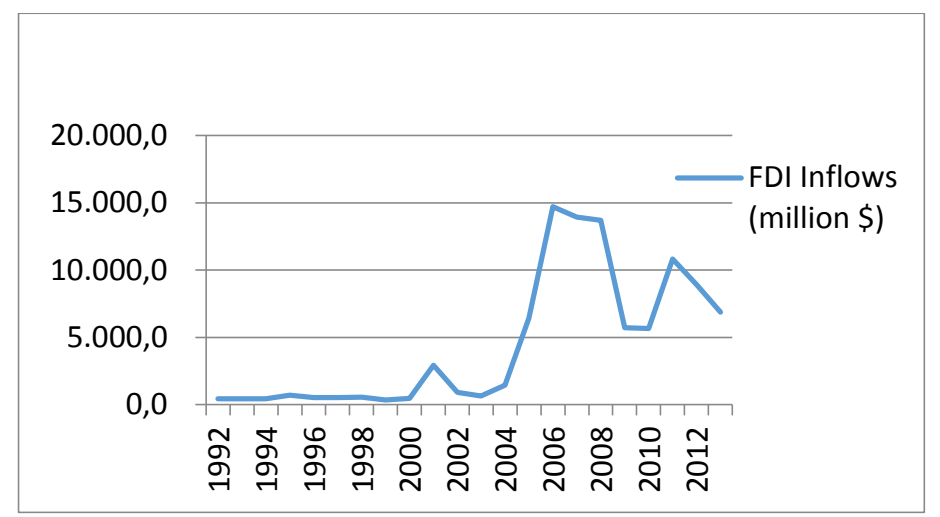

Graphic 2: FDI Flows From EU-27 to Turkey in Million \$ (1992-2013)

Source: OECD Statistics, Data extracted on 04 Aug 2016 from OECD. Stat.

FDI flows are more sluggish until 2002 due to still existing technical barriers and the determinants of FDI flows are more dependent on institutional factors. Accelerating EU accession reforms resulted with higher FDI inflows from the EU. We may follow 2001 Turkish financial crisis and 2008 global crisis effects from the diagram. Falling asset prices caused higher FDI inflows, however global crisis have affected Turkish FDI inflows from the EU negatively.

In addition to these integration indicators different indexes are used by economists to measure economic and political convergence among nations. For instance Konjunktur For Schungsstelle (KOF) index ${ }^{*}$ measures economic, social and political dimensions of

\footnotetext{
‡ Dreher, Axel (2006). Does Globalization Affect Growth? Evidence from a new Index of Globalization, Applied Economics 38, 10, 1091-1110. Updated in: Dreher, Axel, Noel Gaston and Pim Martens (2008), Measuring Globalisation - Gauging its Consequences (New York: Springer).
} 
globalization. We will use Turkish economic globalization index in order to assess economic integration of Turkey with the rest of the world. Since Turkey's integration to the EU is also a part of Turkish trade liberalization and economic globalization, using KOF index is an appropriate approach for our analysis. KOF index of globalization measures economic globalization by using actual flows and trade restrictions among countries. Turkey's KOF globalization index is as seen on Appendix 1 and also economic globalization from 1970 to 2013 is shown in graphic 3.

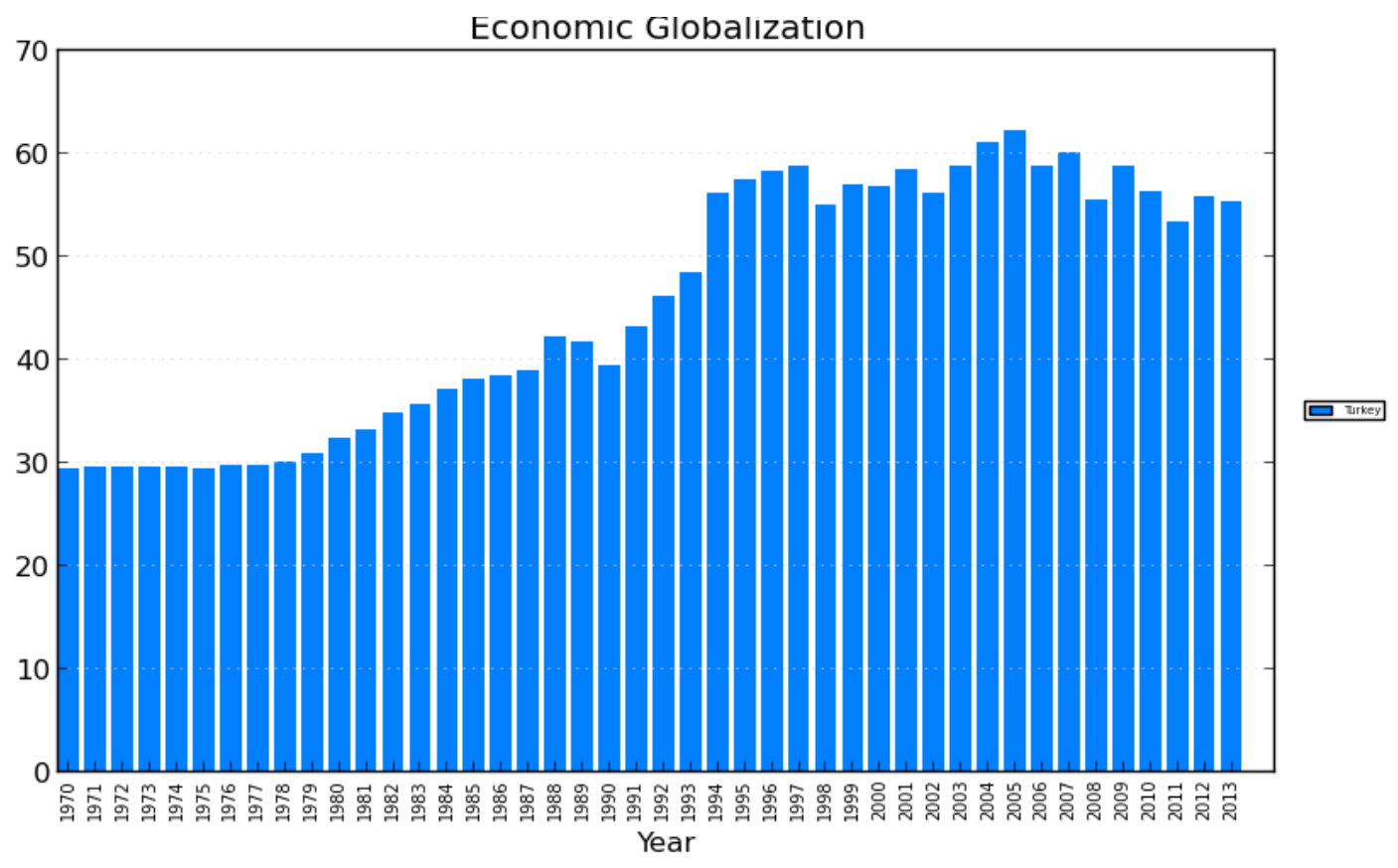

\section{Graphic 3: KOF Economic Globalization Index of Turkey}

Source: KOF Index of Globalization, ETH Zurich, http://globalization.kof.ethz.ch/query/ [Accessed 30 Jan. 2017].

Turkey has reached its highest economic globalization rate in 2005 after economic reforms which are taken by the government to comply with EU's regulations. The impact of these reforms may be seen on trade flows and foreign direct investments as well as economic globalization index. Another important inference from the graphic 3 is that 1995 Customs Union decision leads to lower economic restrictions and higher trade and investment flows between EU and Turkey. On the other hand Turkey's economic globalization index is still very low relative to other countries. According to KOF index Turkey is still 107th in 2016 among 207 countries. 


\section{Revenue Statistics and Calculating Tax Burdens}

Total tax share of public revenues is around 80 percent in Turkey ${ }^{\S}$ and tax revenues are consist of \% 23 of GDP in 2015. This ratio is lower than OECD and EU member states' average. $^{* *}$ The biggest share of total tax revenues comes from consumption taxes such as Value Added Tax (VAT) and excise taxes.

Measurement of tax burden differs in various papers. Calculating tax burdens on factor incomes is a common way to analyze macroeconomic impacts of taxation. Our calculations of average effective tax rates on capital and labor reflect this common approach. Other options such as tax revenue levels in constant prices or in dollar, tax to GDP ratios, tax type to total tax revenue ratios help to assess tax system of countries but in econometric studies these tax burdens may result with biased estimations of the impact of macroeconomic variables.

OECD publishes yearly detailed revenue statistics for each OECD countries. In these statistics tax to GDP ratios are the main indicators to calculate tax burdens for a specific country. OECD's tax to GDP ratios for specific type of tax revenues for Turkey from 1980 to 2013 are listed in Appendix 2.

We may conclude from the Turkish detailed tax statistics (Appendix 2) that the share of indirect taxes has increased from 3.84 percent to 13.98 percent, direct taxes such as corporation and income tax revenues remained low relative to consumption tax burdens. Moreover social security contributions have significant revenue for Turkey in 2000's and the share of those revenues to GDP ratio rises to 8.04 percent in 2013. Higher indirect tax burden and increasing social security payments mean unfair public revenue system for any country. The main problem that developing countries face is financing their economic growth with ineffective and unfair tax system. That type of public revenue systems do not only create unpleasant income distribution but also cause distortions on the functioning of market economy.

We may follow these changes on graphic 4 which shows Turkish consumption tax share of total taxation versus OECD average from 2000 to 2014. Type of tax revenues to total taxation from 2000 to 2014 for Turkish economy is shown below in graphic 4;

\footnotetext{
$\S$ Tax revenues include social security contributions which is an important revenue source of Turkish government.

** OECD, Table A. Total Tax Revenue as Percentage of GDP Revenue Statistics 2015 / Statistiques des recettes publiques 2015 - C OCDE 2015.
} 


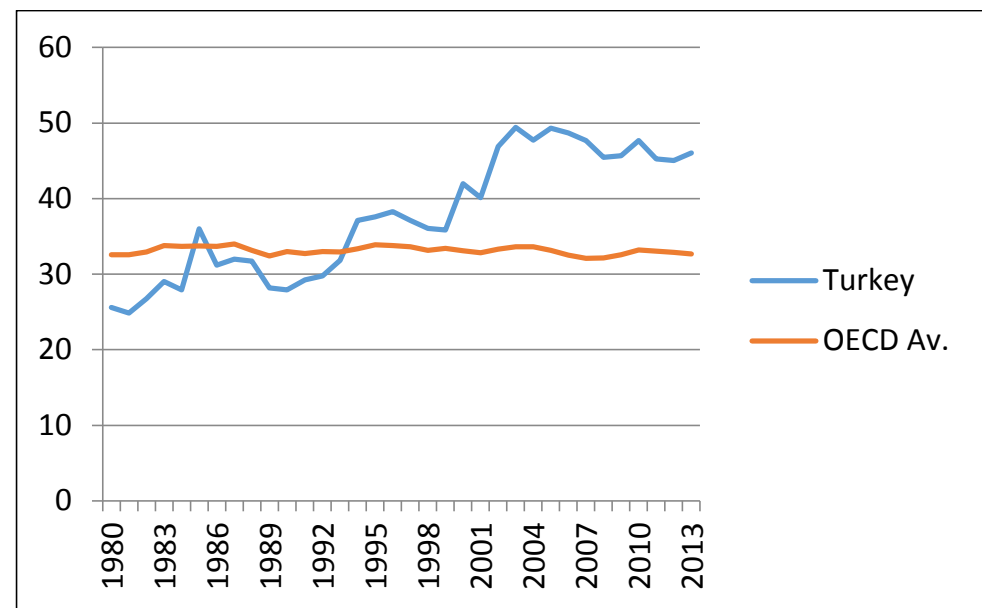

Graphic 4: Tax Revenue From Goods and Services as Percentage of Total Taxation (\%)

Source: OECD detailed tax statistics, Data extracted on 30 May 2016 from OECD. Stat.

According to the method of tax collection; the two main classification in the form of direct and indirect taxation accepted all over the world. Usually, based on the income tax declaration system, corporate tax and inheritance tax, sometimes referred to as direct taxes. If a transaction or a consumption is charged depending on the treatment, this process referred to as indirect taxation. Consumption obtained through taxes is also referred to as indirect taxation and all such taxes cause defections on income distribution. The advantage of this type of tax; only for goods or services can be received over a certain, reducing the consumption of products harmful to health or damage to the environment resulting in the form of negative externalities for the purpose of reducing their adverse effects. Graphic 5 shows the share of direct, indirect taxes and social security contributions as a share of gross domestic product (GDP). 


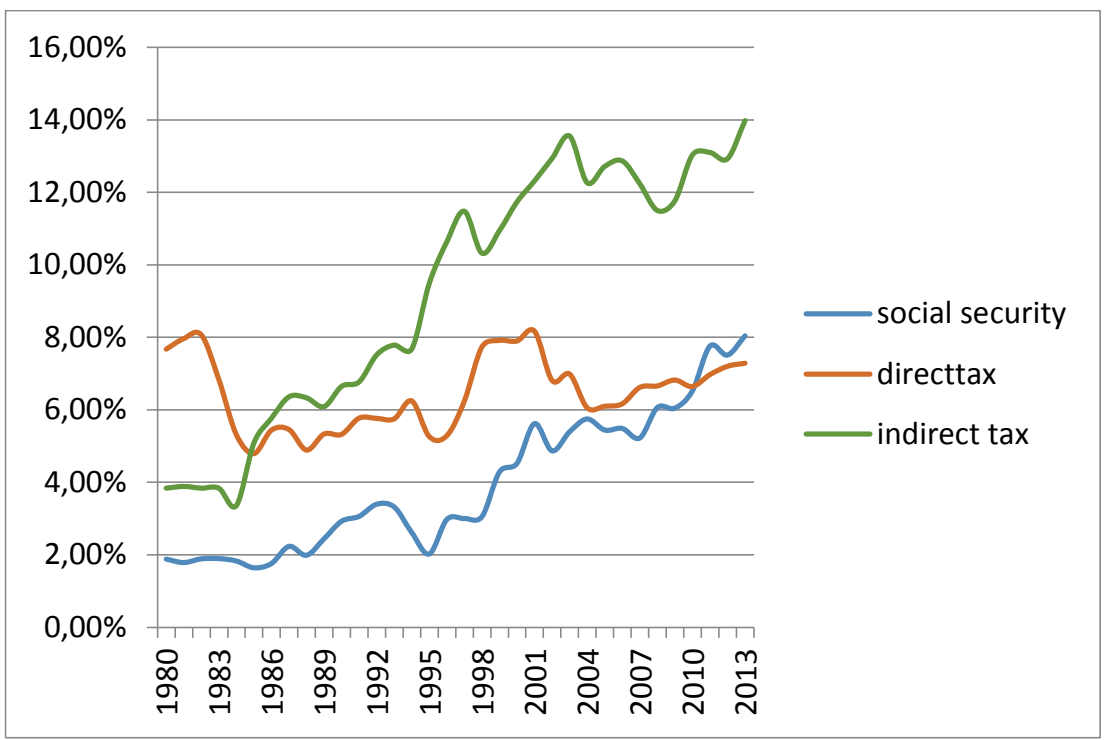

\section{Graphic 5: Direct and Indirect Tax Revenues As Percentage of GDP}

Source: OECD detailed tax statistics.

According to the graphic 5 the share of indirect taxes in total tax revenues is increasing dramatically after 1990 's. This trend is similar for social security contributions contrary to direct taxation.

OECD also publishes tax wedge data yearly but these statistics are calculated for typical households such as one-earner married couple who have two children. In order to analyze tax revenues in macroeconomic models we must aggregate labor force or capital gainers as a production factor. Average effective tax rates are useful to develop macroeconometric models that evaluate macroeconomic impacts of tax policy.

Calculating average effective tax rates for Turkey is a complicated issue due to limited data availability. In a hypothetical household, members of the family can be related to different part of production factors like capital gains or labor income. These income parts may be included in a single unified income statement, which is declared to tax authority by an individual tax payer or a household.

Fourth section demonstrates methods for calculating tax burdens of countries especially for Turkey. Then we will test our paper's main hypothesis which state that there is a positive relationship between economic integration and increasing tax burden on labor which relatively immobile among countries as an application for Turkey. Finally we will discuss results and make policy recommendations for Turkey's tax policy in sixth section. 


\section{Literature Review}

The relationship between globalization and taxation is examined by academics as an interesting research topic. Empirical results of studies show that there is a complicated association between economic integration and tax on mobile production factors. According to previous studies, tax competition among countries to attract FDI and other kind of investments to their countries, does not exist in selected OECD countries with an agglomeration effect of trade (Baldwin \& Krugman, 2004; Borck \& Pflüger, 2006). On the other hand some academics argue that there is a significant negative relationship between corporate tax rates and globalization (Bretschger \& Hettich, 2005). According to Haufler et. al. (2008) corporate tax rates are decreasing because of tax competition about capital attractiveness relative to labor taxes with an effect of multinational companies.

Aizenman \& Jinjarak (2009), categorized public revenues as "hard to collect taxes" (VAT, income taxes, sales taxes) and "easy to collect taxes" (tariffs, inflation tax and financial repression). They find that there is a positive correlation between openness and "hard to collect" taxes but this relationship is negative for easy to collect taxes. The higher trade openness gives rise to hard to collect taxes (Aizenman and Jinjarak, 2009).

Rodrik (1997) explains the effect of globalization on capital taxation and finds negative correlation between capital taxation and globalization, conversely globalization increases tax burden on labor (Rodrik, 1997). According to Monterio and da Silva (2011) open economies' tax revenues are more sensitive to tax rates compare to less open economies. But European enlargement does not have impact on tax revenues of member states (Monteiro, Brandão, \& da Silva Martins, 2011).

According to quantitative analysis of Neumann et. Al. (2009) increasing mobility causes depreciation of tax revenues but the governments are still have enough power to collect revenues. Krogstrup (2004) also states that capital mobility causes tax competiton and reduction of corporate tax rates of countries. The higher public expenditures are meeting with the higher labor taxation. Parallel to this result; Bretschger and Hettich (2005) explains that globalization affects capital tax rates negatively with a panel data estimation for 12 OECD countries.

Aizenman and Jinjarak (2009), categorized public revenues as "hard to collect taxes" (VAT, income taxes, sales taxes) and "easy to collect taxes" (tariffs, inflation tax and financial repression). They find that there is a positive correlation between openness and "hard to 
collect" taxes but this relationship is negative for easy to collect taxes. The higher trade openness gives rise to hard to collect taxes( Aizenman and Jinjarak, 2009).

Studies for specific countries such as Czech Republic (Zimmermannova et. Al., 2016) and for India (Sharma and Singh, 2015) show that tax revenues are dependent on growth rates and regional GDP levels. Çulha (2012), concluded that tax revenues in Turkey have been affected by business cycles.

Our first hypothesis is that closer economic integration changes public revenue levels and increases volatility of public revenues. Especially tax revenues that have high degree of mobility cross borders are connected to economic integration process. Our second hypothesis claims that tax revenues, which have been collected from mobilized production factors, are more dependent on economic integration and have higher volatility than immobile factors. We will test these hypotheses with calculating average effective tax rates of labor and capital for Turkey.

\section{Measuring Average Effective Tax Rates of Turkey}

In order to calculate tax burden of a country or a group of different jurisdictions, different methods have been used by academics. OECD publishes tax revenues to GDP ratio statistics, certain type of tax revenue to total tax revenue ratios yearly and those statistics give deep inside for revenue side fiscal performance of OECD member countries. According to OECD's Revenue Statistics tax revenues are measured by Total Tax revenue divided by gross domestic product (GDP). In northern countries such as Denmark, Norway tax to GDP ratio is very high. Contrary to developed countries, developing countries such as Turkey has lower tax to GDP ratios. In order to analyze tax burden on income factors we need more detailed national account statistics. For Turkey there is no separate statistic for tax burden on labor tax to GDP ratio.

Secondly Mendoza and Tesar (1994) developed a new indicator of tax burden in a country. Devereux and Griffith (2003) analyzed location choice of multinationals by using effective average tax rate (EATR) as an explanatory variable. In this seminal work, Devereux and Griffith developed a new method for EATR and calculated effective marginal tax rate (EMTR) for multinationals' decision of location choice. EMTR is related to investment profitability and multinationals' location decisions.

In our study, we will use tax burden on capital and labor for analyzing the impact of economic integration on tax burdens on production factors. Our calculation is based on 
McDaniel (2007) study of measuring average effective tax rates of 15 OECD countries. Mc Daniel (2007) has developed a new formula in order to calculate AETRs. Formula (1) denotes AETR on labor and formula (2) denotes AETR on capital.

Basic Formulas of Mc Daniel (2007);

$$
\begin{aligned}
\tau h & =\frac{S S+H H T L}{(1-\theta)(G D P-(T P I-S u b))} \\
\tau k & =\frac{H H T C+C T+\mu T P I}{(\theta(G D P-(T P I-S u b))-G O V O S}
\end{aligned}
$$

$$
\tau h=\text { average tax rates on labor }
$$

$S S=$ Social security contributions

$H H T L=$ Total taxes on income of the households

$(1-\theta)=$ Share attributed to labor

$G D P=$ Gross domestic product

$T P I=$ Taxes on production and imports

Sub $=$ Subsidies

$\tau k=$ average tax rates on capital

HHTC $=$ Total capital tax revenue collected from household

$C T=$ Corporate Taxes

$\mu=$ Share of property taxes paid by other entities (assumed0)

GOV OS = Gross operating surplus earned by the government

Basic assumption of the formula is that the tax rate on household labor income is the same as the tax rate on household capital income since national account statistics are not available. To compute (1- $\theta)$ we should know the operational surplus of unincorporated enterprises (OSPUE). We will use as (1- $\theta$ ) International Labor Organization's predictions of labor share of national income of Turkey. Our calculations for Turkey 1981-2014 is shown in Appendix 3. According to our own calculations AETR on labor is increasing but AETR on capital is changing parallel to business cycles and it is more volatile than AETR on labor (Graphic 6 and Graphic 7). 


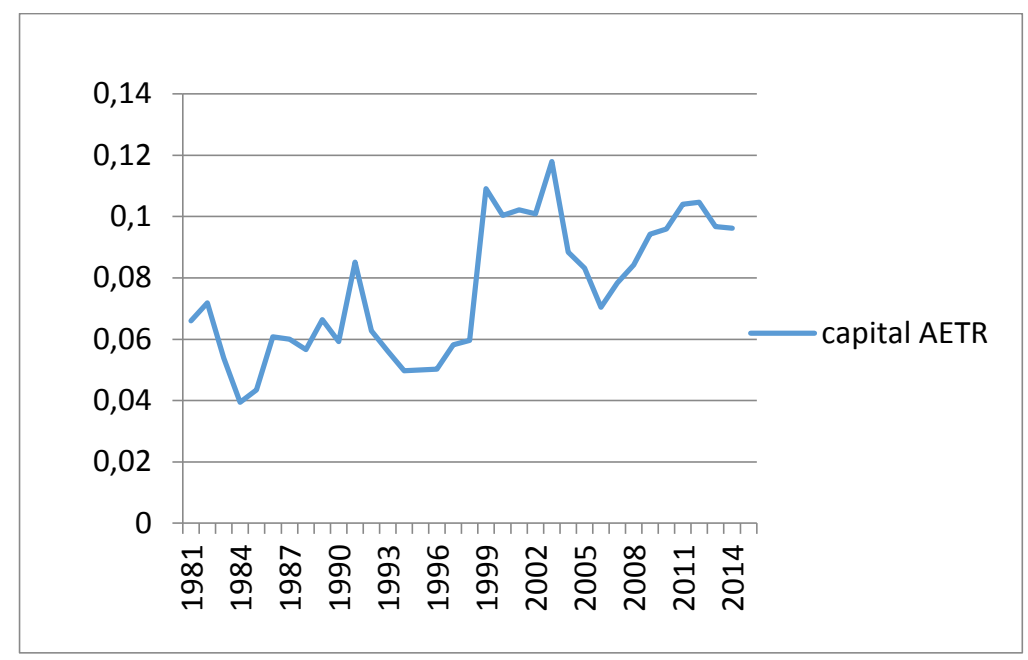

Graphic 6: Average Effective Tax Rate on Capital

Source: Authors' calculations via OECD. Stat.

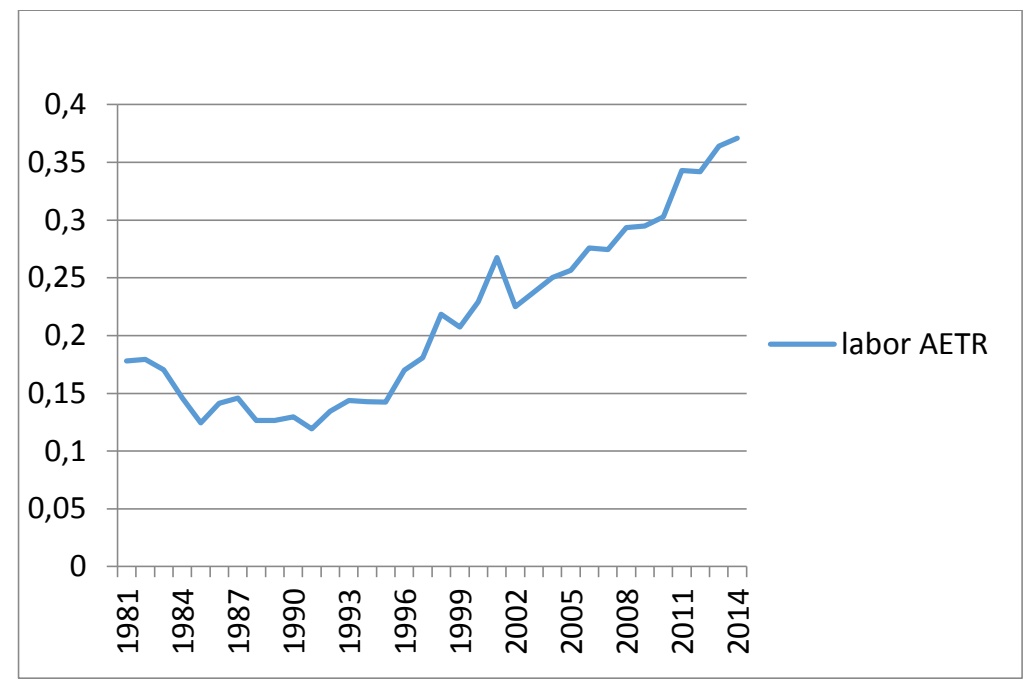

Graphic 7: Average Effective Tax Rate on Labor Source: Authors' calculations via OECD. Stat.

\section{Economic Integration and Average Effective Tax Rates}

Globalization gives rise to economic convergence among nations also it changes public revenue systems of countries. Parallel to removing governments' control on capital, taxation of capital movements is more difficult than before. Our results suggest that in Turkey higher economic integration has caused higher tax burdens on labor relative to capital tax burdens. These results are contradicting to EU's inclusive growth target and labor friendly tax policy in order to reach sustainable growth. 
As a result of non-parametric analysis we may conclude that consumption part of total tax revenues is increasing since 1980 's. This trend also affects labor share of national income indirectly. Decreasing labor share of income and higher consumption taxes give rise to higher average effective tax rates on labor. We have calculated tax burdens on labor and capital based on Mc Daniel (2007) approach which uses Mendoza and Tesar (1994) method. Rising share of consumption taxes, social security contributions and decreasing income share of labor changes tax burden of capital and labor.

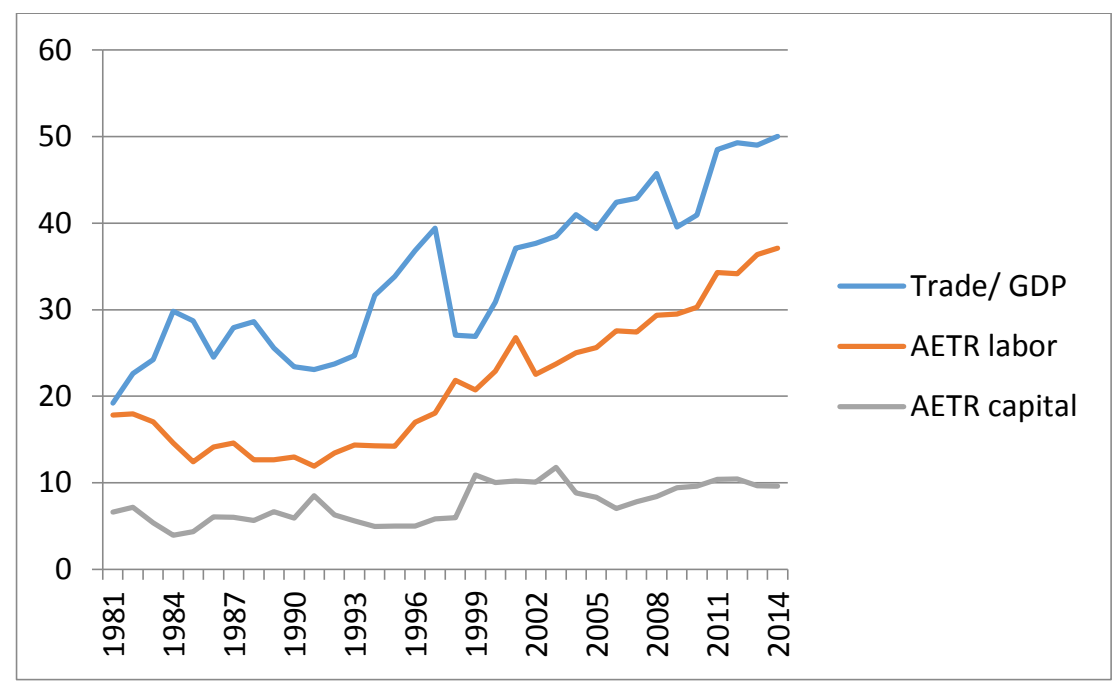

\section{Graphic 8: Correlation Between Trade Openness and Average Effective Tax Rates} Source: World Trade Organization and World Bank GDP estimates, Author's calculations.

Simple correlation coefficient for AETR labor and trade/GDP is 0.86 which means strong positive correlation between economic integration and AETR on labor. For AETR on capital and trade relationship is (0.54). Theory suggests that high mobilized income factor is less dependent on economic integration. High positive correlation among AETR on labor and trade volume shows us immobile production factor is more related to economic integration than it is on mobile income factor.

These results are similar for KOF economic globalization index. Higher economic globalization increases tax burden on consumption and labor. The correlation coefficient for AETR on labor and KOF economic globalization index is 0.62 and it is 0.52 for AETR on capital. Since KOF economic globalization index includes some trade restriction measures the correlation coefficients for KOF index are lower than it is for trade/GDP indicator. 


\section{Conclusion and Policy Recommendation}

Despite limits of Turkish statistical data we have estimated AETR on labor and capital with current national account statistics. With the new publication of these statistics by Turkish National Statistics Agency, we will update these rates. Especially GDP estimations with income approach is crucial for calculation AETRs.

According to our estimations with limited data, there is a strong positive correlation between trade to GDP ratio, which is an important economic integration indicator, and labor tax burden in Turkey. As a result of non-parametric analysis we may conclude that consumption part of total tax revenues is increasing since 1980's. Immobile production factor, labor is affected by globalization with high tax burden. This trend also affects labor share of national income indirectly. Decreasing labor share of income and higher consumption taxes give rise to higher average effective tax rates on labor. Turkish income tax system is progressive but it is not enough in providing equal income distribution system.

Turkish accession to the EU process continues along with trade liberalization policy and consequently with economic globalization. Turkish economic integration to the EU and to other parts of global economy, have also changed Turkish tax system significantly. Because of global trend of increasing debt burdens, countries started to finance their increasing public expenditures with indirect taxes such as VAT and excise tax. Although these consumption taxes are easy to collect, indirect taxes create distortions in economy. Moreover these type of taxes cause unfair income distribution.

In the case of Turkey, as a result of globalization the share of consumption taxes is increasing in total taxation and this process resulted with higher tax burden on labor indirectly. AETR on capital is changing more rapidly with business cycles but there is no strong evidence of higher tax burden on capital. Since computation of corporate taxes are more complicated and there are a lot of loopholes in an economic depression capital tax revenues may depreciate rapidly. But labor taxation is more independent from business fluctuations.

EU's inclusive and sustainable growth policy suggest that more labor friendly taxation is a suitable policy for member states. Turkey should apply more effective consumption taxes such as sugar tax and carbon based taxation and reduce labor tax burden by implementing 
efficient income tax and benefit system. Increasing the efficiency of social security system will also help ensuring more labor friendly tax system.

\section{References:}

Aizenman, J., \& Jinjarak, Y. (2009). Globalisation and Developing Countries - a Shrinking Tax Base? Journal of Development Studies, 45(5), 653-671.

Bretschger, L., \& Hettich, F. (2005). Globalization and International Tax Competition: Empirical Evidence Based on Effective Tax Rates. Journal of Economic Integration, $530-542$.

Çulha, A. A. (2012). Türkiye'de Vergi Gelirlerinin İktisadi Döngülere Duyarlılığı. Ekonomi Notlart. 2012-34. TCMB.

Dreher, Axel (2006): Does Globalization Affect Growth? Evidence from a New Index of Globalization, Applied Economics 38, 10, 1091-1110.

Dreher, Axel, Noel Gaston and Pim Martens (2008), Measuring Globalisation - Gauging its Consequences (New York: Springer).

Globalization.kof.ethz.ch. (2017). KOF Index of Globalization. [online] Available at: http://globalization.kof.ethz.ch/query/ [Accessed at:30 Jan. 2017].

Haufler, A., Klemm, A., \& Schjelderup, G. (2008). Redistributive Taxation, Multinational Enterprises and Economic Integration. European Journal of Political Economy, 24(1), 249-255.

Krogstrup, S. (2004). Are Corporate Tax Burdens Racing to the Bottom in the European Union? EPRU Working Paper Series. Retrieved from http://www.econstor.eu/handle/10419/82018 [Accessed at: 26/11/2016].

McDaniel, C. (2007). Average Tax Rates on Consumption, Investment, Labor and Capital in the OECD 1950-2003. Manuscript, Arizona State University, 1960-2004.

Mendoza, E. G., Razin, A, \&Tesar, L.L. (1994). Effective Tax Rates in Macroeconomics Cross-Country Estimates of Tax Rates on Factor Incomes and Consumption. Journal of Monetary Economics 34, 297-323.

Neumann, R., Holman, J., \& Alm, J. (2009). Globalization and Tax Policy. The North American Journal of Economics and Finance, 20(2), 193-211. https://doi.org/10.1016/j.najef.2009.02.001 [Accessed at 26/11/2016].

OECD detailed tax statistics, Data extracted on 30 May 2016 from OECD.Stat.

OECD, Revenue Statistics 2015 / Statistiques des recettes publiques 2015 - C OCDE 2015.

Sharma, P., \& Singh, J. (2015). Determinants of Tax-Revenue in India: A Principal Component Analysis Approach. International Journal of Economics and Business Research, 10(1), 18-29. 
Unlukaplan, I., \& Arisoy, I. (2010). Turkiye Ekonomisi için Efektif Vergi Oranlarının Hesaplanmast. Discussion Paper, Turkish Economic Association. Retrieved from http://www.econstor.eu/handle/10419/81679 [Accessed at 26/11/2016].

Üngör, M. (2014). Average Effective Tax Rates on Consumption for Turkey: New Data and a Comparative Analysis. CBT Research Notes in Economics. 2014-02. TCMB.

World Trade Organization and World Bank GDP estimates.

Zimmermannova, J., Skalickova, J., Siroky, J. (2016), What Can Tax Revenues Tell us about the Economic Activity of Regions? Economics and Sociology, Vol. 9, No 1, 114-128. 
Doç. Dr. Başak Tanınmış YÜCEMEMiş / Kazım Okan EROL

Appendix 1. KOF Index of Globalization, Turkey

\begin{tabular}{|c|c|c|c|c|c|c|}
\hline & $\begin{array}{c}\text { economic } \\
\text { globalization }\end{array}$ & actual flows & restrictions & $\begin{array}{c}\text { social } \\
\text { globalization }\end{array}$ & $\begin{array}{c}\text { political } \\
\text { globalization }\end{array}$ & $\begin{array}{c}\text { overall } \\
\text { globalization } \\
\text { index } \\
\end{array}$ \\
\hline year & $\mathrm{a}$ & ai & aii & $\mathrm{b}$ & $\mathrm{c}$ & index \\
\hline 1970 & 29.42 & 14.74 & 44.09 & 20.92 & 56.83 & 33.73 \\
\hline 1971 & 29.53 & 14.96 & 44.09 & 20.70 & 57.62 & 33.91 \\
\hline 1972 & 29.53 & 14.96 & 44.09 & 20.56 & 58.66 & 34.14 \\
\hline 1973 & 29.53 & 14.96 & 44.09 & 20.31 & 59.44 & 34.26 \\
\hline 1974 & 29.64 & 15.18 & 44.09 & 20.02 & 60.45 & 34.47 \\
\hline 1975 & 29.39 & 14.70 & 44.09 & 19.76 & 61.24 & 34.50 \\
\hline 1976 & 29.79 & 15.49 & 44.09 & 20.84 & 62.04 & 35.26 \\
\hline 1977 & 29.79 & 15.49 & 44.09 & 21.57 & 63.08 & 35.82 \\
\hline 1978 & 30.08 & 16.07 & 44.09 & 21.86 & 62.99 & 36.00 \\
\hline 1979 & 30.88 & 17.66 & 44.09 & 22.57 & 61.91 & 36.25 \\
\hline 1980 & 32.43 & 20.77 & 44.09 & 23.17 & 60.55 & 36.66 \\
\hline 1981 & 33.21 & 22.04 & 44.37 & 23.69 & 60.19 & 37.03 \\
\hline 1982 & 34.92 & 24.63 & 45.21 & 23.99 & 58.29 & 37.23 \\
\hline 1983 & 35.69 & 25.62 & 45.77 & 24.31 & 61.00 & 38.36 \\
\hline 1984 & 37.09 & 27.31 & 46.88 & 26.28 & 61.30 & 39.67 \\
\hline 1985 & 38.12 & 28.51 & 47.72 & 27.41 & 62.37 & 40.75 \\
\hline 1986 & 38.50 & 29.28 & 47.72 & 36.74 & 62.92 & 44.51 \\
\hline 1987 & 38.92 & 29.85 & 48.00 & 38.11 & 61.27 & 44.72 \\
\hline 1988 & 42.23 & 36.18 & 48.28 & 38.42 & 74.14 & 49.52 \\
\hline 1989 & 41.79 & 35.29 & 48.28 & 38.64 & 71.08 & 48.61 \\
\hline 1990 & 39.50 & 30.44 & 48.56 & 34.72 & 70.79 & 46.26 \\
\hline 1991 & 43.15 & 31.73 & 54.56 & 34.87 & 77.13 & 49.34 \\
\hline 1992 & 46.25 & 33.13 & 59.36 & 40.14 & 77.37 & 52.47 \\
\hline 1993 & 48.46 & 33.52 & 63.41 & 41.07 & 82.73 & 55.06 \\
\hline 1994 & 56.14 & 42.57 & 69.70 & 43.14 & 87.37 & 59.82 \\
\hline 1995 & 57.50 & 38.67 & 76.33 & 44.45 & 87.55 & 60.84 \\
\hline 1996 & 58.29 & 40.17 & 76.42 & 46.51 & 85.04 & 61.20 \\
\hline 1997 & 58.76 & 42.22 & 75.29 & 48.65 & 86.37 & 62.53 \\
\hline 1998 & 55.01 & 35.38 & 74.63 & 48.31 & 85.83 & 60.93 \\
\hline 1999 & 57.02 & 40.18 & 73.86 & 48.65 & 86.85 & 62.05 \\
\hline 2000 & 56.85 & 40.88 & 72.82 & 50.14 & 88.06 & 62.87 \\
\hline 2001 & 58.41 & 49.86 & 66.96 & 50.97 & 89.33 & 64.08 \\
\hline 2002 & 56.24 & 45.17 & 67.31 & 49.50 & 89.59 & 62.83 \\
\hline 2003 & 58.79 & 44.49 & 73.10 & 49.10 & 89.59 & 63.59 \\
\hline 2004 & 61.11 & 43.28 & 78.94 & 49.85 & 89.47 & 64.66 \\
\hline 2005 & 62.22 & 45.46 & 78.99 & 64.38 & 89.47 & 70.47 \\
\hline 2006 & 58.83 & 47.47 & 70.20 & 63.78 & 90.22 & 69.25 \\
\hline 2007 & 60.10 & 50.33 & 69.86 & 64.96 & 87.63 & 69.43 \\
\hline 2008 & 55.45 & 43.54 & 67.36 & 66.51 & 92.45 & 69.68 \\
\hline 2009 & 58.76 & 49.24 & 68.28 & 66.57 & 92.48 & 70.88 \\
\hline 2010 & 56.28 & 47.12 & 65.44 & 66.74 & 92.48 & 70.06 \\
\hline 2011 & 53.39 & 46.93 & 59.86 & 67.37 & 92.50 & 69.28 \\
\hline 2012 & 55.91 & 51.25 & 60.57 & 67.51 & 92.75 & 70.29 \\
\hline 2013 & 55.42 & 49.41 & 61.43 & 67.23 & 92.53 & 69.95 \\
\hline
\end{tabular}


Appendix 2. OECD Detailed Tax Statistics of Turkey (\% of GDP)

\begin{tabular}{|c|c|c|c|c|c|c|}
\hline Year & $\begin{array}{c}\text { Social Security } \\
\text { Contributions }\end{array}$ & $\begin{array}{c}\text { Direct } \\
\text { Taxes }\end{array}$ & Income Taxes & $\begin{array}{c}\text { Individual } \\
\text { Taxes }\end{array}$ & $\begin{array}{c}\text { Corporation } \\
\text { Taxes }\end{array}$ & $\begin{array}{c}\text { Indirect } \\
\text { Taxes }\end{array}$ \\
\hline 1980 & 1.89 & 7.67 & 6.94 & 5.84 & 0.56 & 3.84 \\
\hline 1985 & 1.65 & 4.80 & 4.27 & 3.18 & 1.09 & 5.09 \\
\hline 1990 & 2.93 & 5.33 & 4.99 & 3.99 & 1.00 & 6.65 \\
\hline 1995 & 2.03 & 5.26 & 4.75 & 3.62 & 1.13 & 9.49 \\
\hline 2000 & 4.53 & 7.90 & 7.13 & 5.37 & 1.76 & 11.74 \\
\hline 2001 & 5.62 & 8.17 & 7.53 & 5.75 & 1.78 & 12.32 \\
\hline 2002 & 4.87 & 6.81 & 6.10 & 4.34 & 1.76 & 12.94 \\
\hline 2003 & 5.40 & 6.99 & 6.14 & 4.08 & 2.07 & 13.55 \\
\hline 2004 & 5.75 & 6.06 & 5.32 & 3.58 & 1.75 & 12.27 \\
\hline 2005 & 5.44 & 6.10 & 5.29 & 3.57 & 1.72 & 12.71 \\
\hline 2006 & 5.49 & 6.17 & 5.29 & 3.82 & 1.47 & 12.87 \\
\hline 2007 & 5.22 & 6.62 & 5.72 & 4.09 & 1.63 & 12.24 \\
\hline 2008 & 6.06 & 6.66 & 5.78 & 4.00 & 1.78 & 11.50 \\
\hline 2009 & 6.05 & 6.82 & 5.93 & 4.04 & 1.89 & 11.77 \\
\hline 2010 & 6.52 & 6.64 & 5.58 & 3.68 & 1.90 & 13.03 \\
\hline 2011 & 7.76 & 6.97 & 5.84 & 3.76 & 2.08 & 13.10 \\
\hline 2012 & 7.51 & 7.20 & 6.04 & 3.99 & 2.05 & 12.93 \\
\hline 2013 & 8.04 & 7.29 & 5.93 & 4.07 & 1.85 & 13.98 \\
\hline
\end{tabular}


Appendix 3. Calculations of Turkey's AETRs

\begin{tabular}{|c|c|c|c|c|}
\hline Year & KOF Index & Trade/ GDP & AETR labor (\%) & AETR capital (\%) \\
\hline 1981 & 33.21 & 19.19481438 & 17.81025706 & 6.604002873 \\
\hline 1982 & 34.92 & 22.60236859 & 17.94984046 & 7.191841801 \\
\hline 1983 & 35.69 & 24.25975558 & 17.04570023 & 5.385585171 \\
\hline 1984 & 37.09 & 29.8233489 & 14.59544256 & 3.94779675 \\
\hline 1985 & 38.12 & 28.70679683 & 12.44804897 & 4.3525786 \\
\hline 1986 & 38.5 & 24.51140603 & 14.13429331 & 6.080060283 \\
\hline 1987 & 38.92 & 27.93073404 & 14.591144 & 6.000029862 \\
\hline 1988 & 42.23 & 28.61441364 & 12.6573611 & 5.660991919 \\
\hline 1989 & 41.79 & 25.58908261 & 12.65548932 & 6.645914492 \\
\hline 1990 & 39.5 & 23.4018237 & 12.9610215 & 5.918491432 \\
\hline 1991 & 43.15 & 23.08971557 & 11.93794421 & 8.515475872 \\
\hline 1992 & 46.25 & 23.72094299 & 13.46296896 & 6.27084758 \\
\hline 1993 & 48.46 & 24.70836718 & 14.383266 & 5.611917008 \\
\hline 1994 & 56.14 & 31.65961087 & 14.28512199 & 4.969501868 \\
\hline 1995 & 57.5 & 33.8352548 & 14.24962752 & 4.994903221 \\
\hline 1996 & 58.29 & 36.83746822 & 17.00798755 & 5.019796127 \\
\hline 1997 & 58.76 & 39.41324745 & 18.06559493 & 5.815097307 \\
\hline 1998 & 55.01 & 27.06962189 & 21.83026037 & 5.958167103 \\
\hline 1999 & 57.02 & 26.93037206 & 20.72685786 & 10.91288824 \\
\hline 2000 & 56.85 & 30.8657244 & 22.91515831 & 10.04430618 \\
\hline 2001 & 58.41 & 37.10767199 & 26.75683015 & 10.21720445 \\
\hline 2002 & 56.24 & 37.67741012 & 22.51906059 & 10.08578061 \\
\hline 2003 & 58.79 & 38.4788645 & 23.73164598 & 11.79151581 \\
\hline 2004 & 61.11 & 40.97930138 & 25.03554455 & 8.84351303 \\
\hline 2005 & 62.22 & 39.39087817 & 25.63528043 & 8.318969851 \\
\hline 2006 & 58.83 & 42.40176302 & 27.58412197 & 7.038039208 \\
\hline 2007 & 60.1 & 42.85440251 & 27.43956438 & 7.832879537 \\
\hline 2008 & 55.45 & 45.73101781 & 29.35310019 & 8.428437939 \\
\hline 2009 & 58.76 & 39.55243394 & 29.47847797 & 9.42103163 \\
\hline 2010 & 56.28 & 40.95194673 & 30.29180635 & 9.596978263 \\
\hline 2011 & 53.39 & 48.49906802 & 34.28720721 & 10.40748451 \\
\hline 2012 & 55.91 & 49.31233046 & 34.16904507 & 10.46682585 \\
\hline 2013 & 55.42 & 49.00911264 & 36.39221987 & 9.673793219 \\
\hline 2014 & - & 50.0486392 & 37.09705533 & 9.621561757 \\
\hline
\end{tabular}

